\title{
The first record of Stelidota geminata (Coleoptera, Nitidulidae) in Romania
}

\author{
Melania $\operatorname{Stan}^{1}$ \\ 1 “Grigore Antipa" National Museum of Natural History, 1 Kiseleff Blvd, 011341 Bucharest, Romania \\ Corresponding author: Melania Stan (mstan@antipa.ro) \\ Received 15 April 2019 | Accepted 3 June 2019 | Published 31 July 2019 \\ Citation: Stan M (2019) The first record of Stelidota geminata (Coleoptera, Nitidulidae) in Romania. Travaux du \\ Muséum National d'Histoire Naturelle “Grigore Antipa” 62 (1): 57-60. https://doi.org/10.3897/travaux.62.e35470
}

\begin{abstract}
The strawberry sap beetle, Stelidota geminata originates from the North American continent and was introduced in Europe, the Oriental Region and in the Near East. It is recorded in Romania for the first time.
\end{abstract}

\section{Keywords}

alien species, Nitidulidae, Stelidota, Romania.

\section{Introduction}

Stelidota geminata (Say, 1825) was described from eastern North America (Connell, 1980). The GBIF Backbone Taxonomy (2019) gives a list of fifteen species of Stelidota from all over the world. The Catalogue of Palaearctic Coleoptera (Jelínek and Audisio 2007) presents four species of Stelidota; one of them, S. geminata being an introduced species in Europe, respectively in Austria, Azores, Belgium, France, Italy, Slovenia, Switzerland and Turkey.

In the EPPO region, S. geminata was first introduced in the Azores (Portugal) in the 1980s and later in continental Europe (EPPO 2010). In the subsequent years, the strawberry sap beetle was reported from Germany (Köhler 2009), Hungary (Merkl et al. 2009), Serbia (Spasić et al. 2011), Czech Republic (Vávra et al. 2012), Russian Caucasus (Tsinkevich and Solodovnikov 2014), Slovakia (Jelínek 2014) and Bul- 
garia (Guéorguiev 2018). The species was introduced in the Oriental Region and in the Near East (Köhler 2009).

Adults and larvae of the strawberry sap beetle feed on and contaminate marketable strawberry (Fragaria L.) fruit, being a serious pest in the northeastern United States (Loughner 2008). It has a broad host range (EPPO 2010). The adults are attracted to ripe, overripe and damaged fruits of many plants (Connell 1980). Hagstrum et al. (2013) mentioned peanut and rice as commodities reported to be infested by S. geminata.

Material examined: $7 \hat{\delta} \widehat{\delta}, 2$ q $q+$ were collected from pears (Clapp's Favorite) fallen on the ground; Adunații-Copăceni, Giurgiu county, 26.08.2018, leg. Melania Stan. The material was identified at the beginning of the April, 2019 (Fig. 1A, B).

Remarks: In the summer of 2018, overripe, damaged, fallen pear fruits were observed to be invaded by dozens of small beetles (on each fruit), primarily identified as belonging to the family Nitidulidae. Healthy fruits of the tree were also inspected in order to find out whether they had been attacked and the result was negative. Also, the apples from the ground, with a harder consistency compared to ripe pears, had had only a few specimens of beetles on each fruit.

Sap beetles were not observed on the fallen fruits prior to 2018, either because trees produced no fruit due to frost during sprouting (in 2017), or, when trees pro-
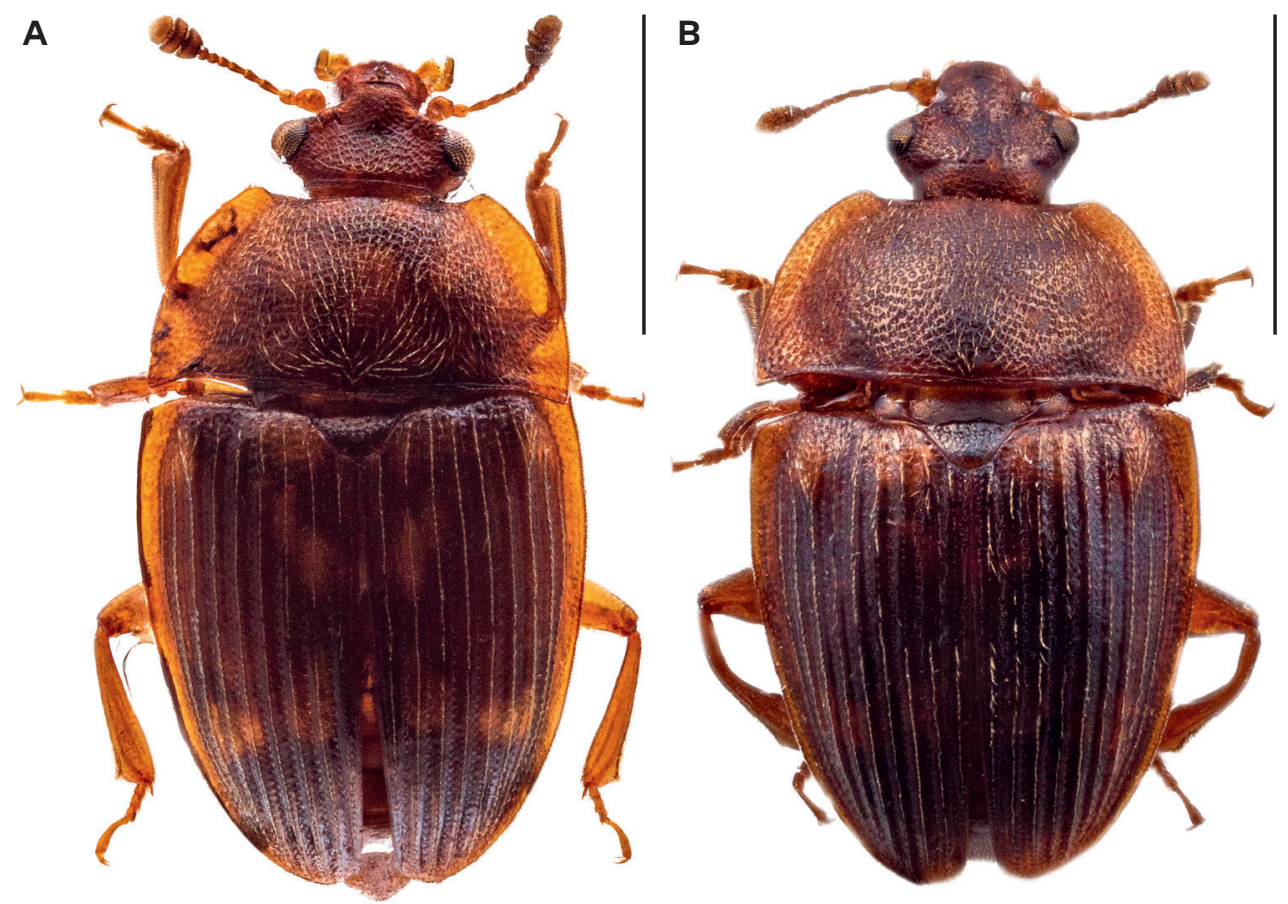

Figure 1. Stelidota geminata, habitus: A. female and B. male. Photographs by I. Iorgu. Scale bar $=1 \mathrm{~mm}$. 
duced fruit, the fallen pears were collected and did not show such attack. After the fruit season, in 2018, sap beetles were not seen on other substrates. Attacked fruits were thrown to compost in 2018. In 2019, the fruits will be checked once they start to ripen and fall and more attention will be payed because there are parcels cultivated with strawberries in this area.

With this collecting site, the alien strawberry sap beetle Stelidota geminata is recorded for the first time in Romania. The specimens are preserved in the Coleoptera Collection of „Grigore Antipa” National Museum of Natural History, Bucharest.

\section{Acknowledgments}

My sincere thanks goes to my colleague Dr. Ionut Iorgu for the photos. I also thank the referees for their constructive comments on my manuscript and for their advice.

\section{References}

Connell WA (1980) Stelidota geminata (Say) infestations of strawberries (Coleoptera: Nitidulidae). Entomological News 91(2): 55-56.

EPPO - European and Mediterranean Plant Protection Organization (2010) Stelidota geminata: another invasive species in Europe? EPPO Reporting Service - Pests \& Diseases, Paris 187: 10-11.

GBIF Backbone Taxonomy (2019) https://www.gbif.org/species/1043977 [Accessed: 2 Apr. 2019]

Guéorguiev B (2018) Coleoptera (Insecta) collected or observed around Chelopech Village, Western Bulgaria. Historia naturalis bulgarica 34: 1-8.

Hagstrum DW, Klejdysz T, Subramanyam B, Nawrot J (2013) Atlas of Stored-Product Insects and Mites. AACC International Press, $589 \mathrm{pp}$.

Jelínek J (2014) Coleoptera: Sphindidae, Kateretidae, Nitidulidae. Folia Heyrovskyana, Series B 21: 1-29.

Jelínek J, Audisio P (2007) Nitidulidae. In: Löbl I, Smetana A (Eds): Catalogue of Palaearctic Coleoptera, Vol. 4. Stenstrup: Apollo Books, 459-491.

Köhler F (2009) Stelidota geminata Say, 1825 (Col., Nitidulidae) - eine neue Adventivart in Deutschland [Stelidota geminata Say, 1825 (Col., Nitidulidae) - a new invasive species in Germany]. Mitteilungen des Entomologischen Vereins Stuttgart 44: 6-8. [in German]

Loughner RL, Loeb GM, Schloemann S, Demchak K (2008) Evaluation of Cultural Practices for Potential to Control Strawberry Sap Beetle (Coleoptera: Nitidulidae). Journal of Economic Entomology 101(3): 850-858.

Merkl O, Lőkkös A, Szalóki D (2009) A szamócafénybogár (Stelidota geminata) Magyarországon (Coleoptera: Nitidulidae) [First records of the strawberry sap beetle (Stelidota geminata) in Hungary (Coleoptera: Nitidulidae)]. Növényvédelem 45(11): 615-617 [in Hungarian]. 
Spasić R, Smiljanić D, Djordjević B, Graora D (2011): Prvi nalaz Stelidota geminata (Say) (Coleoptera: Nitidulidae) na plodovima jagode u Srbiji. [The first finding of Stelidota geminata (Say) (Coleoptera: Nitidulidae) on strawberry fruits in Serbia]. Biljni Lekar (Plant Doctor) 39(4): 419-425 [in Serbian].

Tsinkevich VA, Solodovnikov IA (2014) First record of sap beetles Epuraea ocularis and Stelidota geminata (Coleoptera: Nitidulidae) from Caucasus. Zoosystematica Rossica 23(1): 118-121.

Vávra, JC, Mantič M, Sitek T (2012) Faunistic records from the Czech Republic - 342 Coleoptera: Histeridae, Staphylinidae, Elateridae, Bostrichidae, Nitidulidae, Monotomidae, Laemophloeidae, Cryptophagidae, Corylophidae, Melandryidae, Oedemeridae, Anthicidae, Aderidae. Klapalekiana 48: 297-306. 